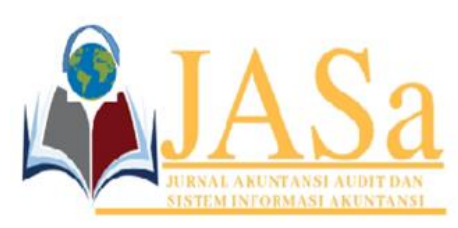

\author{
JASa (Jurnal Akuntansi, Audit dan Sistem Informasi Akuntansi) \\ Vol. 5 No.1/ April 2021 \\ ISSN 2550-0732 print / ISSN 2655-8319 online \\ DOI;10.36555/jasa.v5i1.1588
}

\title{
ANALYSIS OF THE EFFECT OF BUSINESS STRATEGY ON THE QUALITY OF MANAGEMENT ACCOUNTING INFORMATION SYSTEMS
}

\author{
Ayke Nuraliati $^{1^{*}}$, Twenty Selvia Sari Sianturi ${ }^{2}$ \\ Universitas Langlangbuana, Indonesia \\ aykenuraliati@gmail.com ${ }^{* 1}$, twentyselviasari@gmail.com²
}

\begin{abstract}
Management accounting information system (SIAM) is used as a tool to produce financial and non-financial / management accounting information that is used to assist executive managers or internal parties in planning resource allocation, supervision, evaluation, and performance evaluation, both financial performance and non-financial performance including managerial performance and employee performance. Management accounting information systems refer to normative matters, but when management accounting information systems are implemented it has unexpected or unexpected consequences so that it can affect the satisfaction of users of information systems, this is because in the context of the organization and socially not well understood by users. This research was conducted on general insurance in Bandung where the respondents were operational managers using an explanatory survey method. Testing data using simple regression The results of research on insurance companies in Bandung found that business strategies affect the quality of management accounting information systems

keywords: Business Strategy, Management information systems, Accounting Information Systems, Management Accounting information Systems, Management Accounting and Strategy Management,
\end{abstract}

\section{INTRODUCTION}

More specifically, management accounting information is used by management in decision making, resource allocation, monitoring, evaluating, and evaluating performance (Atkinson, et al., 2012). Whereas in insurance companies information system problems according to (Simanjuntak, 2017) say the insurance industry is deemed necessary to immediately provide an integrated information system to minimize the potential for fraudulent claims or fraud for health insurance products with an increasingly widespread hospital cash plan scheme. Furthermore, (Ihsanuddin, 2017) said that farmers and fishermen need insurance products that claim the process is easy because the problem of claims becomes a problem because farmers and fishermen perceive the claim process is not easy to understand and understand by them

The success of business management depends on having a successful business strategy (Weetman, 2006). At this time more and more organizations are aware of the importance of building information systems based on the broad scope of the company and 


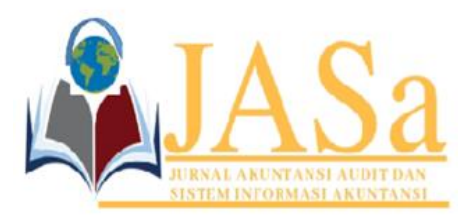

\author{
JASa (Jurnal Akuntansi, Audit dan Sistem Informasi Akuntansi) \\ Vol. 5 No.1/ April 2021 \\ ISSN 2550-0732 print / ISSN 2655-8319 online \\ DOI;10.36555/jasa.v5i1.1588
}

the formulation of business strategies and implementing business strategies in company Furthermore (Laudon \& Laudon, 2012) revealed, in a modern system there is interdependence that grows between the company's information systems and the company's business strategy and business processes (business capabilities).

The Fenomena of business strategy has been pointed out (Hotbunar Sinaga, 2018) that the Indonesian life insurance business has decreased, this can be seen from the performance data released by the Indonesian Life Insurance Association where the insured customers decreased by 9 percent from 58.51 people to 53.27 million people. this is due to unfavorable marketing strategies. In line with this, (Tampubolon, 2019) stated that during the first quarter of 2019 the life insurance business decreased by 11.6 percent as seen from the decline in premium payments to 46.40 trillion. This was agreed by (Robin Winata, 2019), saying that digital marketing is still not optimal, so they are aggressively marketing products digitally to increase insurance premiums. Furthermore, (Toga Pasaribu, 2019) marketing of traditional life insurance products decreased from 43 percent to 37 percent of insurance products and marketing of utilink products increased from 57 percent to 63 percent. This shows that public interest is shifting towards traditional life insurance products and indicates the need for product differentiation in traditional life insurance products. Business strategies according to (Kordi, 2009), (Campbell et al, 2002), (Gamble \& Strickland, 2008), (beer \& Napiewocki, 2000), (Wheelmen et al, 2015), and (Considine et al, 2010) is a method used by companies to achieve corporate goals in winning the business competition and achieving competitive advantage through a variety of integrated activities

Management Accounting Information System According (Bhimani, et al, 2008), (Heidman, 2008). (Kidane, 2012), and (Heidmann, 2008) say that the quality of management accounting information systems in this study is the ability of information systems to provide quality management accounting information that is useful for managers in carrying out management processes. The dimensions of the quality of management accounting information systems according to (Heidmann, 2008) are: Intergration, Flexibility, Accessibility, Formalization, Media Richness. Business Strategy Affecting The Quality Of Management Accounting Information Systems In modern systems/today there is growing interdependence between corporate information systems with business strategies and business processes (business capabilities) of the company, (Laudon \& Laudon, 2012). While (Romney \& Steinbart, 2006) also states that three main factors influence the design of Accounting Information Systems which consist of: the development of Information Technology, business strategy and organizational culture. Furthermore, (Ward \& Pepperd, 2002) state that for an information system to be effective the new top approach is a business strategy needed to be able to manage the information system. (Likewise Gottschalk, 2006) also states that business strategy is the most widespread/diffuse pattern in decision making for resource allocation and other more specific decisions, which affect information systems and information technology, Previous research has produced much empirical evidence that supports the concept of the influence of business strategies on the effectiveness of

Submitted: March 03, 2021; Accepted: March 08, 2021;

Published: April 24, 2021; Website: http://journalfeb.unla.ac.id/index.php/jasa 


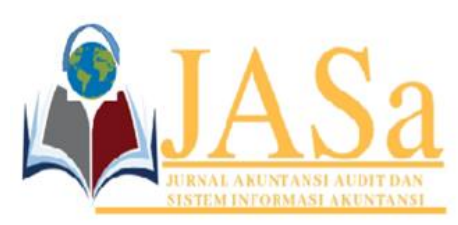

\section{JASa (Jurnal Akuntansi, Audit dan Sistem Informasi Akuntansi) \\ Vol. 5 No.1/ April 2021 \\ ISSN 2550-0732 print / ISSN 2655-8319 online \\ DOI;10.36555/jasa.v5i1.1588}

accounting information systems. Among others, (Xiaoying et.al, 2008) and (Khan et al, 2012) provide empirical evidence that business strategy significantly influences the performance of Accounting Information Systems. Then (Beke, 2011) says business strategies must be supported by appropriate organizational factors such as accounting information systems. Business managers use accounting information to set goals for their organization. The fundamental purpose of management accounting is to help organizations achieve strategic objectives. This is also supported by the research of (Ramlia and Iskandar , 2014) saying that business strategy has a significantly positive effect on the characteristics of MAIS and business strategy has a very dominant influence on the development of MAIS while (Verbeeten, 2010) says business unit strategy and business unit structure influence changes in MACS specific components at the business unit level

\section{METHODS}

\begin{tabular}{lll}
\hline Object of research & $: \begin{array}{l}\text { Business strategy and management accounting information } \\
\text { systems }\end{array}$ \\
\hline Research methods & $:$ Destructive research methods \\
Population & $:$ All insurance in bandung 64 insurance \\
Unit of analysis & $:$ General insurance in Bandung \\
Observation / & $:$ Head of marketing finance \\
$\begin{array}{l}\text { Respondent Unit } \\
\text { Sampling method }\end{array}$ & $:$ Stratified random sampling \\
Minimum number of & $:$ A0 \\
samples & $:$ Using Kuesiorner \\
Data collection & $:$ Primary data \\
method & $:$ Regression analysis \\
Data type &
\end{tabular}

Business strategy

\section{RESULT AND DISCUSSION}

Overall the Business Strategy can be seen in the following table:

Table 1. Recapitulation of Business Strategy Variable Score Achievement

\begin{tabular}{lccc}
\hline \multicolumn{1}{c}{ Dimension } & $\begin{array}{c}\text { Average } \\
\text { Achievement }\end{array}$ & $\begin{array}{c}\text { Achievement } \\
\text { score }\end{array}$ & Criteria \\
\hline Market Orientation & 156 & $78,0 \%$ & good \\
Competitive Advantage & 155 & $77,5 \%$ & good \\
Customer \& Value proposition & 152 & $76,0 \%$ & good \\
Average & 154,1 & 77,1 & good \\
\hline
\end{tabular}

Source: data, processed December 2019 


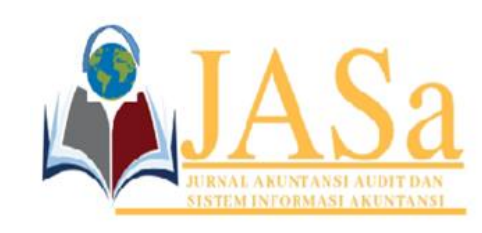

JASa (Jurnal Akuntansi, Audit dan Sistem Informasi Akuntansi)

Vol. 5 No.1/ April 2021

ISSN 2550-0732 print / ISSN 2655-8319 online

DOI; $10.36555 /$ jasa.v5i1.1588

The average achievement score of Business Strategy variables is 154.1 with a percentage of $77.1 \%$. Then the Business Strategy is categorized as good.

Quality Of Management Accounting Information Systems

Table 2. Recapitulation of Achievement Scores Variable Management Accounting Information System

\begin{tabular}{lccc}
\hline \multicolumn{1}{c}{ Dimension } & $\begin{array}{c}\text { Average } \\
\text { Achievement }\end{array}$ & $\begin{array}{c}\text { Achievement } \\
\text { score }\end{array}$ & Criteria \\
\hline Integration & 99,3 & $49,6 \%$ & Less \\
Flexibility & 94,5 & $47,5 \%$ & Less \\
Accessibility & 113,3 & $56,6 \%$ & enough \\
Formalization & 98 & $49 \%$ & Less \\
Media Richness & 103 & $51,5 \%$ & Less \\
Average & 101,6 & $50,8 \%$ & Less \\
\hline
\end{tabular}

Source: data, processed December 2019

The average achievement score of the Management Accounting Information System Quality variable is 109.9 with a percentage of $55 \%$. So the Quality of Management Accounting Information Systems is categorized as less.

\section{Simple Regression Analysis}

Table. 3 Business on the Quality of Management Accounting Information Systems

\begin{tabular}{|c|c|c|c|c|c|c|}
\hline \multirow[t]{2}{*}{ Model } & & \multicolumn{2}{|c|}{$\begin{array}{c}\text { Unstandardized } \\
\text { Coefficients }\end{array}$} & \multirow{2}{*}{$\begin{array}{c}\text { Standardize } \\
d \\
\text { Coefficients } \\
\text { Beta } \\
\end{array}$} & \multirow[t]{2}{*}{$t$} & \multirow[t]{2}{*}{ Sig. } \\
\hline & & $B$ & Std. Error & & & \\
\hline & (Constant) & 938,368 & 379,556 & & 2,472 & ,018 \\
\hline 1 & $\begin{array}{l}\text { Business } \\
\text { Strategy }(X)\end{array}$ & ,959 & , 174 & ,667 & 5,519 & ,000 \\
\hline
\end{tabular}

a. Dependent Variable Quality of Management Accounting Information Systems

Source: data, processed December 2019

Based on the calculation results in the table above, we get the form of multiple linear regression equations as follows:

$$
Y=0.938+0.959 X 1
$$

Submitted: March 03, 2021; Accepted: March 08, 2021;

Published: April 24, 2021; Website: http://journalfeb.unla.ac.id/index.php/jasa 


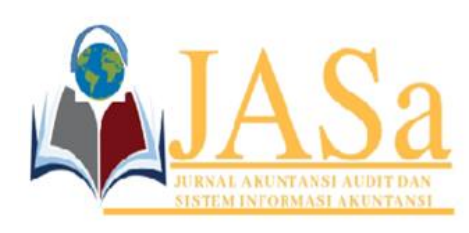

\author{
JASa (Jurnal Akuntansi, Audit dan Sistem Informasi Akuntansi) \\ Vol. 5 No.1/ April 2021 \\ ISSN 2550-0732 print / ISSN 2655-8319 online \\ DOI;10.36555/jasa.v5i1.1588
}

The regression coefficient sign of the independent variable shows the direction of the relationship of the variable concerned with SIAM Quality. The regression coefficient for the independent variable $X$ is positive, indicating a direct relationship between Business Strategy $(X)$ and SIAM Quality $(Y)$. Regression coefficient of variable X of 0.959 implies that for each increase in Business strategy $(X)$ of one unit will cause an increase in the Quality of $\operatorname{SIMA}(\mathrm{Y})$ of 0.959 units

\title{
Effect of Business Strategies on the Quality of Management Accounting Information Systems
}

Based on the provisions that have been stated previously, where obtained a t-test of 5,519 and degrees of freedom $(n-k-1)$ or $23-1-1=22$ obtained the number of $t$ table 2.02 , so that t-count> t-table. This means that $\mathrm{HO}$ is rejected and $\mathrm{H} 1$ is accepted, then there is a significant influence between business strategy on SIAM Quality. Thus the hypothesis which states that there is an influence between Business Strategy on SIAM Quality can be accepted. Table 4. Koefisien Determinasi Pengaruh Strategi bisnis terhadap Kualitas Sistem Informasi Akuntansi Manajemen

\section{Table 4. Business Strategies on the Quality of Management Accounting Information Systems}

\begin{tabular}{|c|c|c|c|c|}
\hline \multicolumn{5}{|c|}{ Model Summary } \\
\hline Model & $\mathrm{R}$ & R Square & Adjusted R Square & $\begin{array}{l}\text { Std. Error of the } \\
\text { Estimate }\end{array}$ \\
\hline 1 & $667^{\mathrm{a}}$ & 445 & 430 & 465,87835 \\
\hline
\end{tabular}

Source: data, processed December 2019

Based on the table above it can be seen that the value of the correlation coefficient is 0.667 then the coefficient of determination (R2) obtained a value of 0.445 . This means that there is an influence between Business Strategy variables on SIAM Quality by $44.5 \%$ while the remaining $33.5 \%$ is influenced by other variables that the researchers did not involve in this study.

Based on the description above can be concluded the hypothesis test is elaborated as follows:

$\mathrm{H} 1$ : Hypothesis is acceptable because there is a significant influence between Business Strategy on SIAM Quality. 


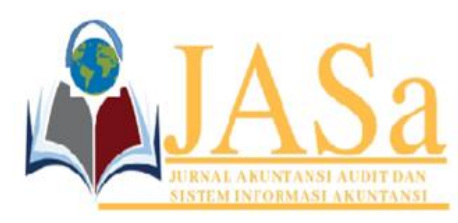

\author{
JASa (Jurnal Akuntansi, Audit dan Sistem Informasi Akuntansi) \\ Vol. 5 No.1/ April 2021 \\ ISSN 2550-0732 print / ISSN 2655-8319 online \\ DOI;10.36555/jasa.v5i1.1588
}

\title{
Effect of Business Strategy on Siam Quality
}

Research results show that there is a positive influence which means that business strategies affect the quality of management accounting information systems in insurance companies in Bandung.

Descriptive, the total value of respondents 'answers about business strategies shows that the General Insurance in Bandung when viewed from the total value of respondents' answers based on various dimensions shows the category of "good" and not optimal. The Business Strategy in this study uses measurements with the dimensions of Market Orientation, Competitive Advantage, and Customer \& Value proposition. The total value of respondents 'answers for the three dimensions used as a comparison, where the value of respondents' answers to the Customer \& Value proposition is smaller when compared to other dimensions, especially in customer access services and ISO quality management certification questions. Then in Competitive Advantage where the price of insurance products and types of products offered. This causes the quality of management accounting information systems in the category of lacking where the dimensions of integration, flexibility, formalization, and media Richness are "lacking", except the accessibility dimension with the category of "sufficient". The aspects of change management that were identified as lacking include the information system component, the integration of information systems between branches or other units, system adjustments, system adaptation, and formality of the system.

So, this research supports the results of (Beke, 2011) research which says business strategies must be supported by appropriate organizational factors such as accounting information systems. Business managers use accounting information to set goals for their organization. The fundamental purpose of management accounting is to help organizations achieve strategic objectives. This is also supported by research by (Ishak Ramlia and Denny Iskandar, 2014) saying that business strategy has a significant positive effect on the characteristics of MAIS and business strategy has a very dominant influence on the development of MAIS. whereas (Verbeeten, 2010) says business unit strategy and business unit structure influence changes in MACS specific components at the business unit level.

\section{CONCLUSION}

Business Strategy influences the Quality of Management Accounting Information Systems. Business strategy is related to the basis for determining short-term and long-term goals and objectives of the company, then the implementation of concrete actions and sharing of resources needed in carrying out various objectives to be achieved by the company. This then influences the quality of management accounting information systems.

\section{DAFTAR PUSTAKA}

Atkinson, A.A., Banker, R.D., Kaplan, R.S. and Young, S.M. 2012. Management Accounting, 3rd ed. New Jersey : Prentice-Hall. 


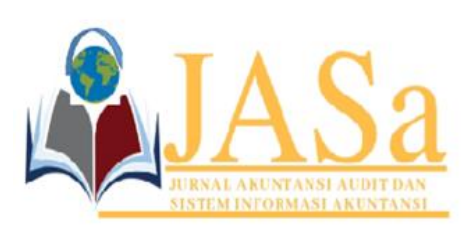

\section{JASa (Jurnal Akuntansi, Audit dan Sistem Informasi Akuntansi) \\ Vol. 5 No.1/ April 2021 \\ ISSN 2550-0732 print / ISSN 2655-8319 online \\ DOI;10.36555/jasa.v5i1.1588}

Beke, Jeno, 2011, International Accounting Standards Effects on Business Management, Business Management and Strategy ISSN 2157-6068 2011, Vol. 2, No. 1: E3

Bhimani, Alnoor. Horngren, Charles T. Datar, Srikant M. Foster, George. 2008 Management and Cost accounting. Fourth edition. Pearson Education Limited

Bing, Chan Chiou, 2011, Which types of management accounting system information can be used to respond adequately to environmental uncertainty? The effects of user participation and tolerance of ambiguity, African Journal of Business Management Vol. 5(34), pp. 13293-13301

Bouwens,Jan. Abernethy, Margareth A. The Concequences of Customization on Management Accounting Systems Design. Accounting, Organizations and Society 25 (2000) 221-241

Brewer, Peter. Garrison,Ray H. Nooren, Eric W 2009 Introduction To Managerial Accounting. Mc Graw Hill Education

Campbell et al, 2002, Business Strategy An Introduction Second Edition, United Kingdom: Butterworth-Heinemann an imprint of Elsevier Science

Gottschaalk, Petter. E Business Strategy: Sourcing And Governance. USA: Idea Publising

Haldma, T. and K. Laats. 2002. Contingencies Influencing The Management Accounting Practices of Estonian Manufacturing Companies. Management Accounting Research 13: 379-400.

Hambrick et al. in Stone and Tudor. 2005. The effect of functional background experience, industry experience, generic executive, management experience on perceived environmental uncertainty and firm performance. Advances in Competitive Research. pp 1-8.

Hansen, D. R.\& Mowen, M. M. 2007. Managerial Accounting. $8^{\text {th }}$ Edition. Thomson.

Heidmann, M. 2008. The Role of Management Accounting Systems in Strategic Sensemaking, $1^{\text {st }}$ Edition. Germany: Deutscher Universitats-Verlag

Hoque Zahirul, 2003, Strategic Management Accounting Concepts, Process, and Issues, second edition, USA: Spiro Press

Horngren, C. T., Sundem, G. L., Stratton, W. O., Burgstahler, D., and Schatzberg, Jeff. 2008. Introduction to Management Accounting, 14 ${ }^{\text {th }}$ Edition. USA: Pearson Prentice Hall

Ihsanuddin, Moch. 2017. Petani dan Nelayan Membutuhkan Proses klaim Asuransi yang Mudah. https://ekonomi.kompas.com/read/2018/11/13/182136226/ojk-petani-dannelayan-butuh-proses-klaim-asuransi-yang-mudah.

Ishak Ramalia dan Deni Iskandar, 2014, Control authority, business strategy, and the characteristics of Management accounting information systems, Procedia - Social and Behavioral Sciences 164 (2014) 384 - 390 International

Julian Noor. 2013. Online Asuransi: 60 Perusahaan belum Terintegrasi. Melalui http//finansial.bisnis.com.

Kourdi Jeremy, 2009, Busines Strategy A Guide to Taking your Business, London: Profile Book Ltd. 


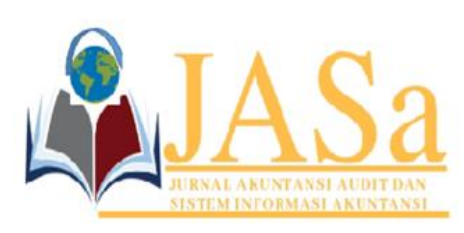

\section{JASa (Jurnal Akuntansi, Audit dan Sistem Informasi Akuntansi) \\ Vol. 5 No.1/ April 2021 \\ ISSN 2550-0732 print / ISSN 2655-8319 online \\ DOI;10.36555/jasa.v5i1.1588}

Kourdi Jeremy, 2009, Busines Strategy A Guide to Taking your Business, London: Profile Book Ltd.

Langabeer, James R \& Napiewocki Jhon, 2000 Competitive Business Strategic For Teaching Hospital, USA: Green Woods Publishing Group.

Laudon, K. C \& Laudon, J. P. 2012. Management Information Systems- Managing The Digital Firm, $12^{\text {th }}$ Edition. Pearson Prentice Hall.

Lucey, Terry. 2003. Management accounting. Fifth edition. Continuum

Moehrle, Stephen R., Moehrle, Jennifer A. Reynorld. 2008. The Proposed Conceptual Framework semantics or Sea Change in financial reporting?. CPA Journal November 2008: 78. 11; ABI/ INFORM Global

Moorhead Griffin, 2013, Prilaku Organisasi, Jakarta Salemba Empat

O'Brien, J. A \& Marakas, G. M. 2010. Introduction To Information Systems, Fifteenth Edition. New York: McGraw-Hill Companies, Inc.,

Palepu, K. G., V. Bernard, dan P. Healy. (2000). Business Analysis and Valuation: Using Financial Statement. South-Western.

Ramalia, Ishak dan Iskandar, Deni. 2014, Control authority, business strategy, and the characteristics of Management accounting information systems, Procedia - Social and Behavioral Sciences 164 (2014) 384 - 390 International

Rani, D. L. \& Kidane, F. 2012. Characteristics and Important Quality Factors of Management Accounting Information System. Radix International Journal of Banking, Finance and Accounting (RIJBFA), Volume 1, Issue 7 (July, 2012). ISSN:2277-100X.

Romney, M.B. and Steinbart, P.J. 2012. Accounting Information Systems, Twelfth Edition. England: Pearson Education

Sekaran, Uma (2013). Research methods for Business: Skill-Bulding Approach., New Y

Setyabudhi, Christine. 2013.Masukan Customer Menjadi Bahan Inovasi Produk Asuransi Cigna. Melalui http://swa.co.id/ceo-interview/masukan-customer-menjadi-bahaninovasi-produk-asuransi-cigna

Simanjutak, Heris B. 2017 FRAUD ASURANSI KESEHATAN : Sistem Informasi Terintegrasi Mendesak. https://papua.bisnis.com/read/20171004/444/695438/fraud-asuransikesehatan-sistem-informasi-terintegrasi-mendesak .

Sinaga Hotbonar, 2018, Bisnis Asuransi Jiwa Menyusut, Klaim Tebus Naik 16,2 Persen. https://finansial.bisnis.com/read/20180828/215/832298/bisnis-asuransi-jiwamenyusut-klaim-tebus-naik-162-persen\#

Sugiyono, 2008. Metode Penelitian Kunatitatif Kualitatif dan R\&D. Bandung Alfabeta.

Sugiyono. 2010. Metode Penelitian Pendidikan Pendekatan Kuantitatif, kualitatif, dan R\&D. Bandung:

Tampubolon Budi 2019, Premi asuransi jiwa turun 11,6\% di kuartal I 2019, berikut penjelasan AAJI. https://keuangan.kontan.co.id/news/premi-asuransi-jiwa-turun116-di-kuartal-i-2019-berikut-penjelasaan-aaji 


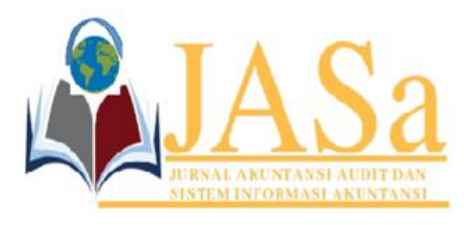

JASa (Jurnal Akuntansi, Audit dan Sistem Informasi Akuntansi)

Vol. 5 No.1/ April 2021

ISSN 2550-0732 print / ISSN 2655-8319 online

DOI; $10.36555 /$ jasa.v5i1.1588

Togar, Pasaribu, 2019. Minat masyarakat bergeser, kontribusi premi produk asuransi jiwa tradisional turun, https://keuangan.kontan.co.id/news/minat-masyarakat-bergeserkontribusi-premi-produk-asuransminat i-jiwa-tradisional-turun

Verbeeten, frank HM. 2010, The Impact of Business Unit Strategy, Structure and Technical Innovativeness on Change in Management Accounting and Control Systems at the Business Unit Level: An Empirical Analysis, International Journal of Management Vol. 27 No. 1 April 2010

Ward, John \& Peppard Joe. (2002), Strategic Planning, for Information Systems, John Wiley \& Sons

Weetman, Pauline. 2010. Management accounting. $2^{\text {nd }}$ Edition. Pearson. England

Winata Robin 2019, Melek pemasaran Digital, https://epaper.kontan.co.id/news/623680/Melek-Pemasaran-Digital

Xiao Ying, Dong et al. 2008, Business performance, business strategy, and information system strategic alignment: an empirical study on Chinese firms TSINGHUA SCIENCE AND TECHNOLOGY ISSN $\square$ 1007-0214 $\square$ 15/26 $\square$ pp348-354 Volume 13, Number 3, June 2008 